\title{
早期胃癌の組織型おっびその組織多様性について
}

\author{
東京医科歯科大学第 1 外科 \\ 石井慶太羽生 丕 \\ 同 第 1 病理 \\ 青 木 望 \\ 土浦劦同病院外科 \\ 真田勝弘
}

\section{A STUDY ON HISTOLOGICAL TYPE AND HISTOLOGICAL HETEROGENEITY OF THE EARLY GASTRIC CANCER}

\section{Keita ISHII and Hiroshi HABU}

The 1st Department of Surgery Tokyo Medical and Dental University, School of Medicine Nozumu AOKI

The 1st Department of Pathology Tokyo Medical and Dental University, School of Medicine

\section{Katsuhiro SANADA}

The Department of Surgery Tsuchiura Kyodo Hospital

\begin{abstract}
胃癌切除例より, その浸潤が粘膜固有層 $(\mathrm{m})$ ととどまる 98 例の $\mathrm{m}$ 癌と, 粘膜下層 $(\mathrm{sm})$ へ漫潤し た68例の sm 癌について, 癌の進展と組織型との関係を検討した. その結果, 低分化腺癌や印環細胞癌 などの未分化型癌の頻度がm癌の23例 $(23 \%)$ から $\mathrm{sm}$ 癌で62例 (38\%) と増加し，また同様に癌の漫 潤面積の増大とともに未分化型癌の増加が認められた。

一方, 組織型の多様性に注目すると, 寸でにm癌において組織像が均一でなく, 同一癌巣内に多様 な組織型が併存する例が半数近くにみられた。この組織多様性の所見より, 癌の深部漫潤や増大にと もなって組織型が分化型癌から未分化型癌への移行を起こす可能性が示唆された。
\end{abstract}

索引用語 : 早期胃癌の組織型, 早期胃癌の組織多様性

\section{I. 緒 产}

乳癌, 甲状腺癌, 白血病などにおいて腫瘍が発育進 展にともなって, 形態学的にも生物学的にも悪性度が 増す。いわゆる悪性転化を起こすことは古くより観察 されている1) . 胃癌に拈いても進行癌を中心にして, その形態学的変化を論じたものが少なくない5～７).

今回，われわれはこのような形態学的変化，とくに 組織型の変化が，すでに早期胃癌の段階でも起こりう るのではないかと考えた，そこで癌の深達度と癌巣面 積を癌の発育運展のひとつの目安とし, 早期胃癌切除 例を対象に病理組織学的所見を調べ以下の検討を加兄

$<1985$ 年 5 月 15 日受理 $>$ 別刷請求先 : 石井 慶太

T113 文京区湯島 $1-5-45$ 東京医科歯科大学第 1 外科
た.

\section{II. 対象と症例}

昭和54年 1 月より昭和 58 年 12 月までの 5 年間に, 土 浦協同病院外科で切除された早期胃癌143症例, 166病 巣を検索対象とした。内訳は男性100例，女性43例で, $\mathrm{m}$ 癌98病巣, $\mathrm{sm}$ 癌68病巣であった。多発胃癌の判定は Moertel ${ }^{8}$ の基準に従ったが, 二重複癌17例, 三重複癌 2 例, 四重複癌 1 例合計 20 例の多発癌を認めた（多発 率は14\%).

病巣は正常部分を含み $5 \mathrm{~mm}$ 幅で切リ出し,ヘマトキ シリン・エオジンで染色し, 症例により切除胃の全割 標本す作製した。

癌の組織分類は胃癌取り扱い規約") (改訂第10版)に よったが, さらに高分化管状腺癌 (tub 1 ), 中分化管状 
図 1 組織構築図の 1 例

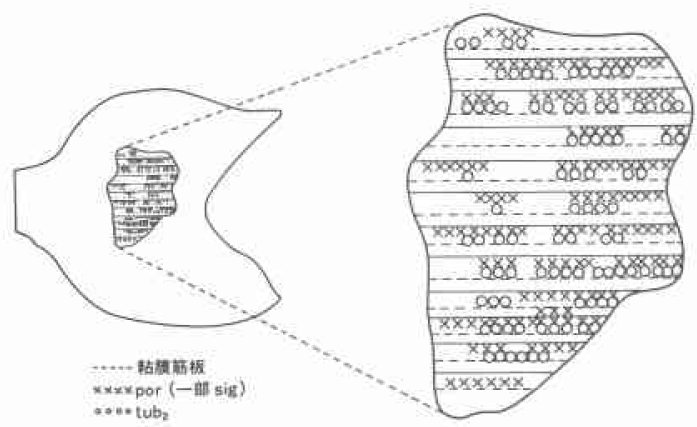

状腺癌 $\left(\mathrm{tub}_{2}\right.$ ), 乳頭腺癌 (pap) を便宣上分化型癌 (以 下 diff と略す) とし，低分化腺癌（por），印環細胞癌 （sig）を末分化型癌（以下 undiff と略す）として組織 型をふたつに大別した 型とする 2 症例と undiff と diff が相半ばして主組織 型を決められなかった 1 例は対象より除外した。主組 織型の決定に際し，図１のような組織構築図を用いた。 すなわち各切片の光顕像を図のよらに粘膜筋板を破線 で示し，それより上層を $\mathrm{m}$ ，下層を $\mathrm{sm}$ とした。ぬたそ れぞれの症例ごとに出現する組織型を記号化すること により，客観的に組織型の主従を決定できるょうにし た.

癌巣の面積は構築図上での最大径とそれに直交する 径の積をもって近似値とみなした．主組織型と異なる 組織型が二切片にまたがり認められるか，一切片のみ に限定されていてもその組織型が拡がりを持ち，面を 構成している場合にその組織型を従組織型と規定し た。

早期胃癌の肉眼分類は日本消化器内視鏡学会に従 い, I, I+IIb, I+IIa, IIa, IIa + IIcなどを隆起型，IIc， IIc +IIa, IIc +III, III+IIcなどを陷凹型に大別した。

推計学的処理は $x^{2}$ 検定により,危険率 $5 \%$ 以下を有 意差ありとした。

\section{III. 結 果}

早期胃癌166病巣の組織型を，ずその優勢像により diff と undiff の 2 群に大別し，両群の癌を比較した結 果以下の成績が得られた。

1）年龄。性別と組織型

diff, undiff の癌が同一胃内に多発している 5 例を除 き, 男女別に diff, undiff の割合を求めると, 男性95例 では diff が72例 (76\%) で, undiff は23例 (24\%) で あり，女性43例では diff が22例 $(51 \%)$ で, undiff が 21例（49\%）を占めていた，女性では男性に比べ明ら
かに undiff が高頻度であった（ $\mathrm{p}<0.01 ）$.

年齢構成は27歳から78藏に至り, diff の平均年齢 60.0歳に対して undiff のそれは47.8歳であり， undiff は若年に頵いていた。

2）肉眼型と組織型（表 1)

diff 107例のらち隆起型は38例（35\%)，陥凹型は69 例(69\%)であったのに対し，undiff の47例では隆起型 はわずか 2 例 (4\%) に過ぎず，陥凹型が45例（96\%） と大部分を占めていた $(\mathrm{p}<0.001)$.

3）澡達度と組織型（表 2 )

$\mathrm{m}$ 癌98病巣では diff が75例 (77\%), undiff が23例 (23\%) であり，一方 sm癌68病巣ではdiff が42例 (62\%), undiff が26例 (38\%) で, sm 癌ではm癌に比 ベ undiff の比率が有意に高かった（p<0.05）.

4) 癌栄面績と組織型

表 3 のように面積を4ランクに分けて検討した. 40 $\mathrm{cm}^{2}$ 以下と $25 \mathrm{~cm}^{2}$ 以下の間で若干 undiff の占める割合 は減少をみせるが，全体としては面積の増大にとも

表 1 肉眼型と組織型

\begin{tabular}{c|c|c}
\hline & diff & undiff \\
\hline $\begin{array}{c}\text { elevated } \\
\text { type }\end{array}$ & $38(35)$ & $2(4)$ \\
\hline $\begin{array}{c}\text { depressed } \\
\text { type }\end{array}$ & $69(65)$ & $45(96)$ \\
\hline total & $107(100)$ & $47(100)$ \\
\hline \multicolumn{2}{|c}{}
\end{tabular}

表 2 深達度と組織型

\begin{tabular}{c|c|c|c}
\hline 深達度 & $\mathrm{m}$ & $\mathrm{sm}$ & total \\
\hline diff & $75(77)$ & $42(62)$ & $117(70)$ \\
\hline undiff & $23(23)$ & $26^{*}(38)$ & $49(30)$ \\
\hline total & $98(100)$ & $68(100)$ & $166(100)$ \\
\hline \multicolumn{3}{|c}{${ }^{*} \mathrm{p}<0.05,()$}
\end{tabular}

表 3 癌巣面積と組織型

\begin{tabular}{c|c|c|c|c}
\hline $\begin{array}{c}\text { 面皘 } \\
\left(\mathrm{cm}^{2}\right)\end{array}$ & $1.0 \geqq$ & $4.0 \geqq$ & $25 \geqq$ & $25<$ \\
\hline diff & $35(85)$ & $32(64)$ & $39(70)$ & $11(58)$ \\
\hline undiff & $6(15)$ & $18(36)$ & $17(30)$ & $8^{*}(42)$ \\
\hline total & $41(100)$ & $50(100)$ & $56(100)$ & $19(100)$ \\
\hline \multicolumn{3}{|c|}{$* 0<0.05,(\quad) は \%$}
\end{tabular}


なって undiff が増える傾向が認められた $(\mathrm{p}<0.05)$.

5）癌巣面積別にみた sm 癌の割合（図 2)

面積をさらに細かく 6 ランク $\left(1 \mathrm{~cm}^{2}\right.$ 以下, $4 \mathrm{~cm}^{2}$ 以下, $9 \mathrm{~cm}^{2}$ 以下, $16 \mathrm{~cm}^{2}$ 以下, $25 \mathrm{~cm}^{2}$ 以下, $25 \mathrm{~cm}^{2}$ より大き もの)に分け, 組織型別に各面積群の中での $\mathrm{sm}$ 癌の占 める割合を比べた， diff においては面積が増すに従っ て sm 癌の占める割合が増して行き， $25 \mathrm{~cm}^{2}$ より大き い癌では $91 \%$ sm $\mathrm{sm}$ で浸潤しており, 癌浸潤の広さ と樑さとの間に相関を認めた。

一方, undiff でも同様に, 癌巣面積の増大に従って $\mathrm{sm}$ 癌の割合は増加し, 癌巣面積が $16 \mathrm{~cm}^{2}$ になると $\mathrm{sm}$ 癌が100\%を占めていた。しかし，さらに癌巣面積の広 い癌では $\mathrm{sm}$ 癌の占める割合は $50 \%$ とむしろ減少し た。面積が $16 \mathrm{~cm}^{2}$ 上り大きく，深達度が的であった undiff の 6 例は, 全例 U1 III 以上の深い潰瘍洀痕をそ の癌巣内に有することが特徵的と思われ，またりンパ 節転移を認めた 1 例も含まれている。

6) 深達度と組織多様性

次に対象を病巣全体が均一の組織型よりなる simple type と, 複数の組織型よりなる complex type に 分けて検討を加えた。

まず深達度別にその割合をみると，表 4 に示すよう

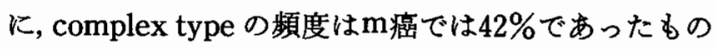
が $\mathrm{sm}$ 癌では $85 \%$ と有意に増加した $(\mathrm{p}<0.01)$.

7) 癌巣面積と組織多様性の関係

表 2 と同様に面精を 4 ランクに分けて, 組織多様性 との関係を調べた. complex type の頻度は面積が増大

\section{因 2 癌巣面積別にみた $\mathrm{sm}$ 癌の割合}

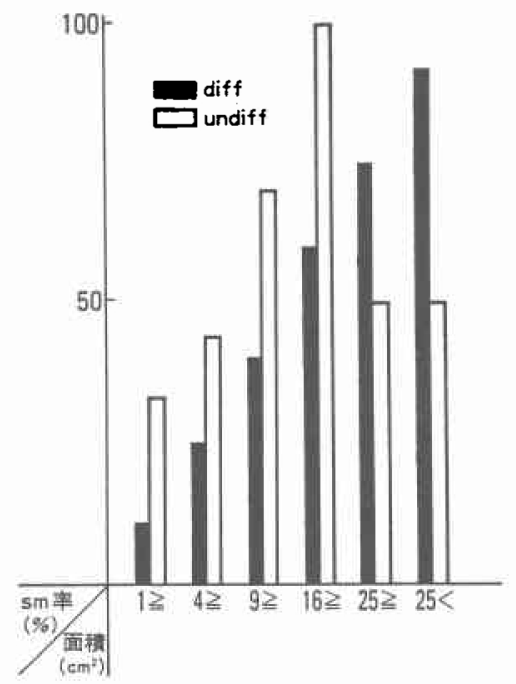

表 4 深達度と組織多様性

\begin{tabular}{l|c|c|c}
\hline 組織 & $\mathrm{m}$ & $\mathrm{sm}$ & total \\
\hline simple & $57(58)$ & $10(15)$ & $67(40)$ \\
\hline complex & $41(42)$ & $58^{*}(85)$ & $99(60)$ \\
\hline total & $98(100)$ & $68(100)$ & $166(100)$ \\
\hline \multicolumn{3}{|c}{${ }^{*} \mathrm{p}<0.01,(\quad)$ ( $\% \%$}
\end{tabular}

表 5 癌巣画積と組織多様性

\begin{tabular}{l|c|c|c|c}
\hline $\begin{array}{c}\text { 面皘 } \\
\text { 組織 }\end{array}$ & $1.0 \geqq$ & $4.0 \geqq$ & $25 \geqq$ & $25<$ \\
\hline simple & $34(83)$ & $17(34)$ & $14(25)$ & $2(10)$ \\
\hline complex & $7(17)$ & $33(66)$ & $42(75)$ & $17^{*}(90)$ \\
\hline total & $41(100)$ & $50(100)$ & $56(100)$ & $19(100)$ \\
\hline & & \multicolumn{3}{|c}{${ }^{*} \mathrm{p}<0.01,(\quad) は \%$}
\end{tabular}

するに従い， $17 \% ， 66 \% ， 75 \% ， 90 \%$ と明らかな增加 を示した（p<0.01）（表 5 ）.

また 1 つの癌巣を構成する組織型が単一である simple typeをさらに組織型が diff 系 $\left(\mathrm{tub}_{1}, \mathrm{tub}_{2}\right.$, pap)である simple diff と, undiff 系 (por, sig) であ る simple undiff の 2 群に分けた. これに対して1つの 癌巣が 2 つ上異なる組織型より構成される complex type において，量的に多い組織型を主組織，少な い方を従組織型と呼んだ。従組織型が 1 種類でない時 は多いものより第 1 従組織型, 第 2 従組織型と名付け た。 その結果 complex type は diff > diff' (主組織型が $\mathrm{tub}_{1}, \mathrm{tub}_{2}$ すしくは pap のいずれかで, 従組織型が主組 織型と異なる diff type (diff') で形成されるすの), diff $>$ undiff (主組織型が diff で, 従組織内に undiff 持つもの), undiff $>$ diff (主組織型が undiff で, 従組織 内に diff を持っもの), undiff $>$ undiff $^{\prime}$ (por か sig の 一方が主組織型で, 他方が従組織型 (undiff') のもの) の 4 型に亜分類された。このらち undiff $>$ undiff'はm 癌で 4 例, sm 癌では 6 例であり, 全体の中で占める割 合は低かった。表 6 はこれらの組織型の組み合わせが, 癌巣の面積別にどのような頻度でみられるかを調べた むのである。

図 3 は癌巣面積別に simple type と complex type の 2 つの type の癌の出現頻度をグラフ化したもので ある. simple typeの頻度は $1.0 \mathrm{~cm}^{2}$ 以下の小さい癌で は $85 \%$ と非常に高いが，面積増大につれ急峻な减少を 
表 6 癌巣面積別にみた組織型の組み合わせとその頻度

\begin{tabular}{l|r|r|r|r|r|r}
\hline \multicolumn{1}{c|}{ 面積 $\left(\mathrm{cm}^{2}\right)$} & $1.0 \geqq$ & $4.0 \geqq$ & $9.0 \geqq$ & $16 \geqq$ & $25 \geqq$ & $25<$ \\
\hline simple diff & $30(73)$ & $16(32)$ & $5(17.2)$ & $6(31.6)$ & $1(12.5)$ & $2(11)$ \\
\hline simple undiff & $3(7.7)$ & $0(0)$ & $1(3.4)$ & $2(10.5)$ & $0(0)$ & $0(0)$ \\
\hline diff $>$ diff, & $3(7.7)$ & $6(12)$ & $6(20.1)$ & $4(21)$ & $1(12.5)$ & $3(16.6)$ \\
\hline diff $>$ undiff & $1(2)$ & $10(20)$ & $8(27.9)$ & $6(31.6)$ & $2(25)$ & $5(25.7)$ \\
\hline undiff $>$ diff & $1(2)$ & $10(20)$ & $7(24.5)$ & $1(5.3)$ & $4(50)$ & $8(44.6)$ \\
\hline undiff $>$ undiff, & $3(7.7)$ & $8(16)$ & $2(6.9)$ & $0(0)$ & $0(0)$ & $0(0)$ \\
\hline total & $41(100)$ & $50(100)$ & $29(100)$ & $19(100)$ & $8(100)$ & $18(100)$ \\
\hline
\end{tabular}

図 3 癌巣面積別にみた組織多様性の頻度

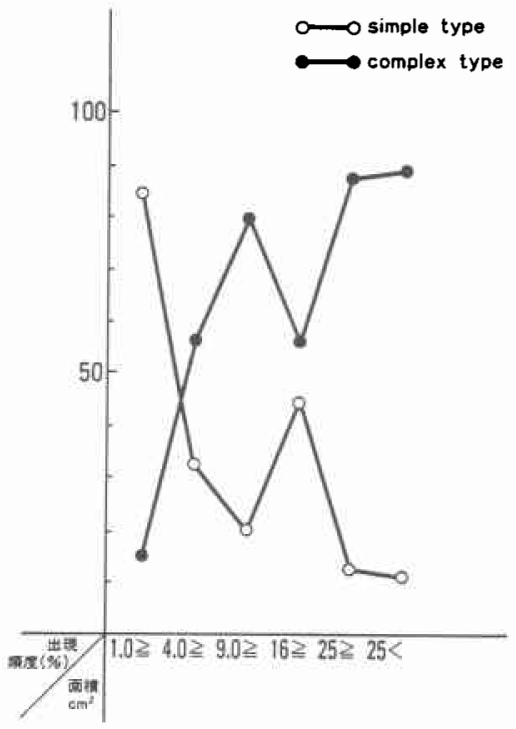

示し, 途中一時的増加を見せるが, $25 \mathrm{~cm}^{2}$ 以下, $25 \mathrm{~cm}^{2}$ より大きい癌では $10 \%$ 程度の低頻度となる.一方 complex type は $1.0 \mathrm{~cm}^{2}$ 以下の小さい癌では $15 \%$ と低頻度 であるが，面積の増大とともにその頻度を增す傾向が 明らかである。表 6 の成績を併せみると, $4.0 \mathrm{~cm}^{2}$ 以下 か5 $9.0 \mathrm{~cm}^{2}$ 以下の中等度の大きさの癌では主に diff $>$ undiff の増加が, $25 \mathrm{~cm}^{2}$ 以下, $25 \mathrm{~cm}^{2}$ より大きい癌 では undiff >diff が増加が，図 3 に示される complex typeの急激な増加の主因をなしていることがわかる。

\section{IV. 考 察}

今回，対象を外科的に切除された早期胃癌に限って 検討したが，次の点に慎重な配慮をした。すなわち目 的が胃癌の発生から $\mathrm{m}, \mathrm{sm}$ へと進展していく時の, 組
織型を中心とした動的変化を知ることなので，われわ れが用いた対象症例が早期胃癌の一般的な傾向を正し

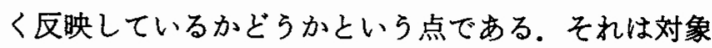
を昭和54年以降の症例に限り, それ以前の症例を除外 した理由ともなっている。当施設の症例は昭和 45 年よ り始まるが，昭和 40 年代，50年代前半は胃癌全体に占 める早期胃癌の割合いが小さく，中には進行癌として 手術され, 病理組織学的検索で初めて早期胃癌と診断 された症例も少なくない。このように早期胃癌発見の 診断技術や，このための地域医療体制が十分整ってい ない時代の，いわば片寄った症例を含めることが早期 胃癌全体を知る上で不適当ではないかと考えられたか らである。

具体的には全早期胃癌中の $\mathrm{m}$ 癌の占める割合が高け れば高いほど，また発見される早期胃癌の面積が小さ ければ小さいほど, 発生初期の胃癌の発育過程を知る 上で適当であると考光られる。ちなみに昭和 58 年度に 切除された早期胃癌中のm癌率は66\%で, 年度をさか のぼるにつれ $\mathrm{m}$ 癌が減少し sm 癌が増加する傾向にあ り，今回対象とした 5 年間に㧋ける早期胃癌での平均 m癌率は $59 \%$ であった。

われわれは早期胃癌のらちでも, より深い癌, より 広い癌に扣いて undiff type の癌の頻度が高くなるこ とを観察した。この観察事実を説明するひとつの仮説 として，筆者らは癌の進展につれ組織型を diff type か $ら$ undiff type へと移行させる一群が存在するのでは ないかと考六た。より梁い癌, より広い癌ほど complex type の癌の頻度が高くなるという観察事実は, 癌 の組織型が決して不動なるのでないことを示唆する所 見と思われる。しかし，今回の研究は同一の癌を経時 的に観察したものではなく, 癌巣面積もしくは深達度 
とい5尺度に従って，それぞれ独立した数多くの早期 癌を並べて，1つの癌の成長に伴う組織型の变動を類 推するといら方法をとったわけであり，その解积に揖 いては持のずから限界があることは否めない。

従来より胃の進行癌に関しては, 形態学的に分化度 の高い組織型から低い組織型への移行が観察され, 報 告されている(5) 7)12). 遠城寺(5)613)14)は手術材料では分 化の良い腺癌が多く, 剖検材料で硬性癌ないし単純癌 が反対に多くなることを観察し，これは剖検材料の方 がより時間を経た癌で，そのために組織型の推移が起 こると述べている. 海江田 ${ }^{15)}$ は早期胃癌から進行胃癌 までの外科手術材料を詳細に観察し, 組織像の多様珄 はすでに粘膜癌においても多く存在し, 癌が進行した すのほど多様性が增すと報告している．彼はこの組織 多様性について, 癌の多中心発生の可能性は否定でき ないにしても,粘膜内に止る早期胃癌に打いてさえ, 通常各組織型間に連続性ないしは移行像が認められる ことが多いことから, 二次的に組織型の移行が起こっ たためであろうと述べている.

われわれの症例でも，早期胃癌全体の $60 \%$ において 組織像の多様性が認められた。この頻度が，14\%とい ら今回の早期胃癌の多発率よりはるかに多いこと，ま た明らかに衝突癌と判定しらる組織像を持った症例が 1 例も認められなかったこと, さらに海江田の報告と 同様に各組織型に連続性ないし移行像が通常見られた こと,などより組織多様性の説明として多中心性発生 の関与がさほど大きなるのではないと推察された ${ }^{16)}$.

田内ら ${ }^{177 \sim 20)}$ は癌の組織多様性と, 増殖経過にした がって起こる組織像の変換の主な要因を癌間質を含む 環境に求め, 1 例として早期胃癌と進行胃癌, あるい は若年者と老年者での間質の違いを指摘している.

桐本 ${ }^{21)}$ 剖検例を中心に検討を加光, 主病巣の組織 像に多様性を認めるものが全体の $66 \%$ あり, 深部に浸 潤する浪と硬性癌が増し，とくに結合織の増生の強い 層ほど組織多様性が著しい傾向を認めたと報告し, 組 織多様性の成立が癌と周囲間質との相互関係の結果生 じるのではないかと述べている.

今回の症例で癌巣内に潰瘍または潰崵痗痕を持つ59 例中 39 例 (88\%) に組織多様性を認めたが, Ul (一) の107例では46例 $(42 \%)$ にすぎなかった $(\mathrm{p}<0.001)$. $\mathrm{sm}$ 癌の潰瘍性病变合併の有無で $\mathrm{sm} の$ 組䄽型を比較 すると, Ul (十)群のうち典型的な Ul III ないし Ul IV の深い潰瘍もしくは漬瘍洀痕を合併した10例中 9 例の mは diff 系と undiff 系の癌が混在する complex type
で構成され, smは 8 例が por の simple type, 1 例が por > tub 2 の complex type で，いずれる洀痕性結合織 内を scirrhous に浸潤していた。一方, Ul (一)群は37 例でそのうち 9 例は m, smを同一から単一の simple type の癌で構成して, diff 系が 7 例, undiff 系が 2 例 であった。 また complex typeではあるが diff 系のみ で $\mathrm{m}, \mathrm{sm}$ を構成していた癌が 9 例, undiff 系のみで $\mathrm{m}$, sm を構成していた癌 7 例存在した。 それに対してm と sm の diff, undiff type 別での優勢組織型が異なる 症例は12例で, 全例がmを diff $>$ undiff, sm undiff $>$ diff または undiff のみで構成しており，今回の症例の 中にはmを undiff 采, sm diff 系とする癌は存在し なかった，以上ょり潰瘍病変の有無にかかわらず, 癌 $の \mathrm{~m} \rightarrow \mathrm{sm}$ といら深部浸潤にともない diff $\rightarrow$ undiff となる組織型の変化の方向性が観察されたが, 逆の undiff $\rightarrow$ diff の方向性は見出せなかった。 また smに 存在する組織型は必らずmに認められるが, mの組織 型のすべてが sm に反映されるすのではなかった。す なわち $\mathrm{sm}$ 癌の組織多様性の頻度が高い原因は $\mathrm{sm} て ゙$ の組織多様性によるものではなく，mでの組織多様性 に基づくものと思われた。

併 ${ }^{221}$ は, 早期胃癌の $27.8 \%$ に組織多様性を認め, そ の理由として同一癌巣において発生当初より性質を異 にする癌があったのではないかと推測している。

太田 ${ }^{23224)}$ は癌の組織多様性の成因として, 胃癌発生 当初より多様性を持つ場合と, 均一な組織像が途中よ り多様性を持つに至る場合を想定し, 後者の原因を実 質之間質の相互作用に求めている.

また新たな観点として，胃癌の核 DNA 量と組織型 または深達度, 進行度との関係からのアプローチも注 目される. 清水 ${ }^{25}$ 注早期胃癌を単独組織型と混合組織 型に分けて，それぞれ低分化腺癌と高分化腺癌の DNA ヒストグラムパターンを検討している。それに よると低分化腺癌単独型ではs stem line のプロイディ が低く，分散の幅が小さいのに対して，混合組織型の 低分化腺癌部分は同一病変部の高分化腺癌よりるさら に強い偏倚を示し、このことより混合組織型の低分化 腺癌は単独組織型の低分化腺癌とは異質で, 高分化腺 癌から变異して生じた可能性も考えられると結論つけ ている。一方蒲池ら ${ }^{26}$ は深部浸潤という視点より DNA ヒストグラムパターンの変化を観察し, 多くの 初期の胃癌は diploid 系の細胞であるが, 癌の生長, 漫 潤に伴って polyploidization が進行する群と初期の増 殖動態が DNA パターン上維持される群に分けられる 
とし, 前者は分化型癌に後者は未分化型に対応すると 述べている。このように，これまでにも胃癌の組織型 がその進展過程で分化型癌から未分化型へ变化する可 能性を示唆した報告は少なくない。

今回，われわれはこのような組䅧型の变化は早期胃 癌の時期に起こるのではないかと考光, 光顕レベルの 形態学的検討に的を絞り行った. その結果, 深達度が $\mathrm{m}$ より $\mathrm{sm}$ へ深くなるにつれ，また癌面積が増大す るにつれ, diff type の癌が減り, undiff type の癌が増 えるといら事実が観察された。るちろんすべての早期 胃癌が同じ速さで梁部浸潤をしたり, 水平方向に払 がっていくわけではなく, 症例の中にも最大径 $5 \mathrm{~mm}$ 以 下の微小胃癌でありながら smまで浸潤していた。い わゆる penetration typeの癌や， $5 \times 5 \mathrm{~cm}^{2}$ 以上の広い 面積を持らながら， $\mathrm{m}$ に止まる superficial sprending type の癌も認められた。

癌巣内の潰瘍㓔痕も癌の深さ，広さを大きく修飾し ているよらに思われる。たとえば粘膜筋板が断裂し粘 膜下層が線維化で置き換っている $\mathrm{m}$ 癌の中には, 一度 $\mathrm{sm}$ まで浸潤した癌が漬湯化により脱落消失し，見か け上癌になったものも含まれる可能性がある27)28).

また，潰瘍の㴒痕収縮のために面積がかえって縮むこ ともありらると思われる ${ }^{2930)}$. このように深達度にし ても, 癌巣面積にしても, 癌の成長過程を推し測る正 確な目安とは言いがたく，なにを癌進展の尺度とする かについてはいまだ解決がなされていない。しかし， 例外的な症例を除き，深達度と面積とい52 つの側面 から種々の澏を見比べた時, これら 2 つの要因が増す につれ, 形態学的に分化度の低い組織型の頻度が高く なると言える.

次に胃癌の深達度がmから sm へと進展するとなぜ undiff type の癌が増加するかを考察してみた。 まず癌 の組織型が一定で变移しないものと仮定すると, 考光 られるひとつの可能性としては, 癌が sm 一浸潤する 過程で diff type の癌そのものが減少するといら考兄 方であろら。この中には diff type の癌の絶対数の減 少，すなわち脱落消失が起き減少する場合と, sm 一漫 潤する速度が undiff type の癌より遅いために相対的 減少を来す場合のふたと扔りが考えられる。しかて diff type の癌は undiff type の癌に比へ，一般に高齢 者に多く, 腸上皮化生をともなった萎縮粘膜に囲まれ, 胃液も無酸, 低酸の症例が多いことなどから, diff type の癌が undiff type の癌に比べ,ょり脱落しやすい状況 にあるとは思われない.一方 diff type の癌としての性
格を見ると，図2のように面積扗大とともに順当に smに浸潤して扣り，これからも脱落消失を示唆する データはない. また表 1 のうに diff type の癌の35\% は隆起型で, いわゆる増殖という癌らしい性質を素直 に表現するものが多い，さらに癌巣内の潰瘍を検索す ると, diff type では U1(+) 例の頻度は23\% (115例中 26例) で, undiff type における67\% (49例中33例) に 比べ明らかに潰瘍合併率が低い。これらの所見からも diff type の癌の脱落消失の可能性は否定的である.

次に, 組織型の違いと浸潤速度の差異に関しては以 下の上うに考兄ている.すなわち $\mathrm{m}$ sm の間には粘 膜筋板があり，これは癌浸潤に対して胃壁の各層間に はない強力なバリヤとして働いているものと思われ る. しかし粘膜下層と固有筋層間にはこのようなバリ ヤとして介在するるのはなく，筋束間の疎な結合織へ と連続している。したがって $\mathrm{sm}$ といら空間に対して $\mathrm{m}$ よ入り込んで来る癌と, $\mathrm{sm}$ より $\mathrm{pm}$ へ出ていく癌 を想定すると, 癌はむしろ的で定み, 結果として $\mathrm{sm}$ 癌 より 癌の方が多くなるよらに推測される。これは, ある時点で各層内に存在する胃癌の割合は癌がその層 に入ってから出るまでの所見時間に相関すると考えら れるからである. 事実, 同期間に切除された深達度 $\mathrm{m}$, sm, pmのdiff typeの癌の比率はそれぞれ $56 \%$ (75 例), $31 \%$ ( 42 例), $13 \%$ (18例) で $\mathrm{m}$ 癌の占める割合 がもっとも多く,上述の推論の妥当性をらかがわせる. しかし undiff type の癌で同様の比較を行うと $\mathrm{m} 42 \%$ (23例), sm 47\% (26例), pm 11\% (6 例) となり $\mathrm{sm}$ 癌の占める割合がもっとも多くなり，これを説明する ためには, mから smへの浸潤速度に対して, smから $\mathrm{pm}$ への浸潤速度が遅いので sm に癌が淀むといら少 し不自然な仮説を立てなければならなくなる。

ふたつめの仮説は $\mathrm{m}$ から sm へ進む過程で undiff type の癌が増加するという考え方である.その増加の 大きな要因として表現型を diff type として発生した 癌の一部が, 進展過程で undiff type の癌に変わる可能 性である，癌を構成する組織型の多様性について観察 すると, $\mathrm{m}$ 癌の約半数がすでに simple typeではなく, $\mathrm{sm}$ 癌では complex type はさらに増加して $85 \%$ 占 めていた。次に癌巣面積と組織多様性の関係をみると, 面積増大に従って組織多様性を示すすのがやはり著明 に増加していた。すなわら胃癌はすでに早期癌の段階 から, 進展にともなって組織多様性を増加させている と言光る. 典型的具体例をみると, 图 4-a は深達度m の, 直径 $5 \mathrm{~mm}$ 以下の微小癌で simple type とした症例 
図 4-a 最大径 $5 \mathrm{~mm}$ の微小癌, $\mathrm{HE}$ 染色 $(\times 100)$

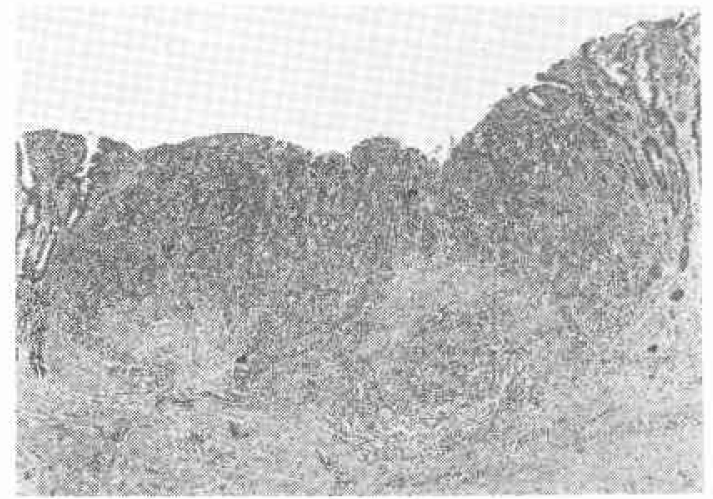

図 4-b 表層拡大型で粘膜下層に por が漫潤してい る. $\mathrm{HE}$ 染色 $(\times 80)$

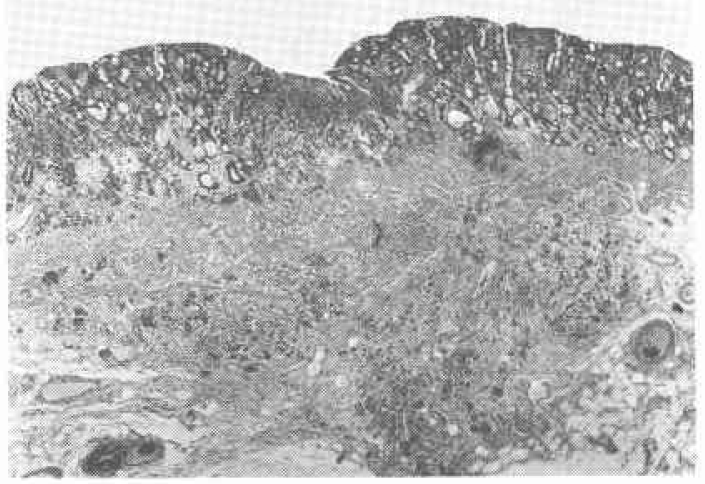

図 4-c 表層部は $\mathrm{tub}_{2}$, 深部および先進部は por で構 成される. HE 染色 $(\times 40)$

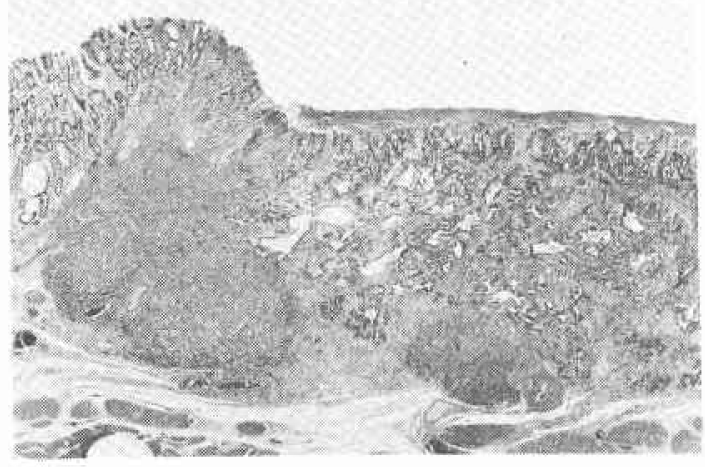

である、この例のよらにごく初期の癌でも, 表層部で は腺管構造を形成する $\mathrm{tub}_{2}$ から成るが，先進部はすべ に腺管構造を失った髄様性分化型癌への移行像らしい
所見が認められる。图 4-b は表層拡大型の IIc で深達 度はsmで, 主組織型 $\mathrm{tub}_{2}$, 従組織型 por とした症例 である、癌の主体は $\mathrm{m} て ゙ ~ t u b_{2}$ と por がモザイク様に混 在し, 中央部の por 部分の直下で smにやはり por が 浸潤している. 図4-c は IIa+IIc の深達度 sm で主組 織型が $\mathrm{tub}_{2}$, 従組織型が por の complex type に分類 した症例である。表層部怙よび中心部では明らかに腺 管構造を呈した tub 2 がみられ，より深い先進部から周 辺領域で低分化型癌が膨脹性に増殖している。これら の症例を並べてみると，早期胃癌の発育進展にとも なって分化型癌, 特に中分化管状腺癌の一部が低分化 型癌に移行していく流動的なパターンが想像される. 図 4-a のごとく癌の初期像とも思われる症例に早く も組織多様性の兆しが現われ, 図 4-bではmで従組織 型の porのみが sm で認められ，また図 4-c 湾の中 心部の切片だが，辺縁の切片では tub $_{2}$ と por の比率は すでに逆転していて，いずれ癌巣全体でも por が $\mathrm{tub}_{2}$ よりも優勢となりそうな様相を呈している.

complex type の症例をみると一般的には $\mathrm{tub}_{2}$ の浅 部または深部もしくは先進部に高頻度に por, pig が出 現する. 図3のグラフによると $1.0 \mathrm{~cm}^{2}$ 以下の小さい癌 では圧倒的多数を占める simple type の癌が面積増大 とともに急激な減少をみせ，それに対して complex

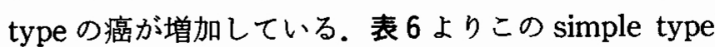
の減少は大部分 simple diff の减少によるもので, complex type の増加は中等大の癌では diff $>$ undiff, 大きな癌では undiff >diff の増加によることがわか る. 面積増大につれ早期胃癌の症例数が減ってくるた め, これらの推論は十分批判に耐兄られるるのではな いが，面積増大にともなって生じる組織多様性の，こ の変化は, 癌進展による主組織型の変化と関わり合い を持つようである.

進行癌に颃いて，その組織型が経時的により分化度 の低いるのに変化していく場合があるといら報告は少

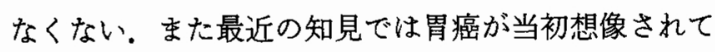
いたより，はるかに長期間を钐止まっているとされ ている ${ }^{31)}$.このことを踏を学るなら早期胃癌とはい党 組織型の多様性が認められるのはさほど不自然な観察 事実ではなく，たとえばmから smへと浸潤していく 間に, diff type の癌に undiff type の部分が出現し, , さらに時間経過とともに undiff type の癌が全体の中 で優位となる可能性も否定できないと思われる。言い 換えるならば undiff typeの癌には発生的に異質のむ のが存在している可能性がありこれらは今後形態学 
的検索のみならず前述の核 DNA 量による検討や，癌 の持っている腫場抗原などを検索して明らかにしなけ ればならないと思われる。

\section{V. 結U}

1）早期胃癌の深達度がmから sm 一と進むに従い 末分化型癌の頻度が増加した。

2）早期胃癌の癌巣面積が増大するに従い未分化型 癌の頻度が増加した。

3）早期胃癌がmから sm と進行するに従い組織 多様性を示す癌の頻度が増加した。

4）早期胃癌の癌巣面積が増大するに従い組織多様 性を示す癌が増加した。

5）小さい癌巣面積では simple diff type の癌が大 多数であったが, 面積増大とともに diff > undiff もし くは undiff >diff の complex type の癌が増加した。

以上の所見より早期胃癌においても癌の進展につ れ, 主組織型を diff type から undiff type 一之移行さ せる癌が存在する可能性が示唆された。

稿を終るにあたり，御指導，御助言を賜った恩師，札煶医 科大学第 1 病理学教室菊地浩吉教授ならびに第 2 病理学水 無瀬昂講師に心より感謝いたします。

本研究の要旨は第43回日本癌学会総会にて発表した。

$$
\text { 文献 }
$$

1）遠城寺宗知：人癌腫組織像の時期的推移. 日病理 会誌 $47: 203-220,1958$

2）河西信勝, 坂本穆彦：甲状腺癌の悪性転化. 癌の臨 29: 105-109, 1983

3) Foulds L: Neoplastic Development. Academic Press, London, 1969, p67-85

4) Nowell PC: The clonal evolution of tumor cell populations. Science $194: 23-28,1976$

5）遠城寺宗知：胃癌の組織学的構築とその意義につ いて. 福岡医誌 $46: 496-520,1955$

6）遠城寺宗知, 海江田統：胃癌の進展と組織像。鹿児 島大医誌 $16: 660-670,1965$

7）今井環, 田中健蔵：胃癌の発育状況之組織像。福 岡医誌 43:676-693，1952

8) Moertel CG, Bargen JA, Soule EH: Multiple gastric cancers. Gastroenterology 32 : 1095-1103, 1957

9）胃癌研究会編：胃癌取扱い規約. 改訂第10版，東 京, 金原出版, 1979

10）中村恭一：胃癌の病理. 京都, 金芳堂, 1972, p191 $-214$

11) Lauren $P$ : The two histological main types of gastric carcinoma: Diffuse and so-called intestional type carcinoma. Acta Pathol Microbiol Scand $64: 31-49,1965$

12）今井 環：剖検例と手術とに拈ける胃癌組織像の 比較. Gann 40：199-201，1949

13）遠城寺宗知, 古賀 序: 胃癌術後 5 年経過後の再 発. 胃々腸 $12: 33-40,1977$

14）遠城寺宗知：初期胃癌の組織学的検索. 癌の臨 $7: 96-99,1961$

15）海江田統：胃癌の病理組織学的研究補遗. 鹿児島 大医誌 $17 ： 247-276,1965$

16）太田邦夫, 田中 良：胃の衝突癌. Gann 43 ： $210-212,1952$

17）田内 久, 林活久, 佐藤秩子ほか：癌腫に打汀る 組織像の変換に関する病理学的研究. Gann 48 ： $357-359,1957$

18）田内 久, 佐藤秩子：癌の発育增殖と年齢. 老年病 $6: 309-318,1962$

19）佐藤秩子：癌組織像の形態变化についての病理学 的研究. 名古屋大医会誌 $9: 77-98,1958$

20）三浦 橎：胃癌の組織像と進展相に及ぼす年龄要 因. 日老医会誌 $5: 262-263 ， 1968$

21）桐本孝次：胃癌原発巣々転移巣の組織形態学的考 察. 大阪大医誌 $10: 1223-1852,1958$

22）云瓶善郎：組織像からみた胃癌の進展形式につい て. 日外会誌 $80: 446-456,1982$

23）太田邦夫，田中 良：胃癌各組織型の発生分布に ついて. Gann 43:367-370, 1952

24）太田邦夫，田中 良：癌組織に於ける多形性につ いて. Gann 42:181-187, 1951

25）清水 實 : 早期胃癌の組織型と顕微分光測光法に よる核DNA 量との関係。大阪大医誌 $29: 473$ $-489,1977$

26）蒲池正浩, 諸富直文, 橋本敏和ほか：深達度よりみ た胃癌の DNA-RNA 頭学光測光法による解 析. 癌と化療 $11: 2342-2347,1984$

27）村上忠重：胃潰瘍癌に関する新しい考点方。順天 堂医 $13: 157-165,1967$

28）今井 環：胃癌発生母地としての消化性潰瘍一病 理組織学の立場から一。 日臨 $22: 1902-1908$, 1964

29）渡辺英伸, 西巻 正：胃癌の発育, 進展に影響する 因子. 癌と化療 $10 ： 482-488,1983$

30）八尾恒良, 渡辺英伸 : 陥凹性胃癌の発育進展過程 とその病理像. Prog Dig Endosc 3:171-175, 1973

31）中村恭一, 芦沢貞六, 高田 洋传か：胃癌の大きさ と時間の関係。胃と腸 $13: 89-93,1978$ 